Важливою передумовою ефективності мовленнєвої діяльності майбутнього вчителя $є$ оволодіння їі технікою, компонентами якої є голос, дикція, темп, ритм, інтонація, паузи. Названі компоненти - це своєрідна акустична система «відтворення людини людиною». Вони виконують важливі функції, зокрема створюють імідж людини, сприяють виявленню іiі індивідуальних психічних особливостей, передають емоційний стан мовця.

У системі формування мовленнєвої культури майбутнього вчителя важливо усвідомлювати основні функції, які має виконувати мовлення. Автори навчального посібника «Педагогічна майстерність» за редакцією І. Зязюна виокремлюють такі основні функції педагогічного мовлення: комунікативну - встановлення і регуляція стосунків між учителем і учнями, забезпечення гуманістичної спрямованості розвитку вихованців; психологічну створення умов для забезпечення психічної свободи вихованців, вияву індивідуальних особливостей особистості, зняття соціально-фізіологічних затисків; пізнавальну забезпечення оптимальних умов для сприймання навчального матеріалу учнями, формування в них емоційно-ціннісного ставлення до знань; організаційну - забезпечення раціональної й ефективної пізнавальної діяльності учнів [1].

Отже, формування мовленнєвої культури майбутніх учителів філологічних спеціальностей залежить від таких чинників: по-перше, повинна бути створена цілісна, єдина програма, спрямована на формування культури мовлення студентів-філологів, що пов’язує всі фахові дисципліни: практичний курс української мови, культуру мови, сучасну українську літературну мови, стилістику, риторику тощо. По-друге, повинна розвиватися належним чином самостійна пізнавальна діяльність студентів засобами мови. Також текстові, інформаційні та інші матеріали в підручниках та посібниках з фахових дисциплін повинні більше використовуватись задля розвитку правильного мовлення майбутнього вчителя.

1. Зязюн I. А. Педагогічна майстерність: підручник [Електронний ресурс]/ І. А. Зязюн, Л. В. Крамущенко, І. Ф. Кривонос. - Київ : Вища шк., 1997. - Режим доступу до pecypcy : http://www.ex.ua/5074950. 2. Іванишин В. Я. Мова і нація: тези про місце і роль мови в національному відродженні України / Іванишин В., Радевич-Винницький Я. Дрогобич, 1994. - С. 93-94. 3. Мацюк 3. Українська мова професійного спілкування / 3. Мацюк , Н. Станкевич. - Київ : Каравела, 2005. - 352 с. 4. Окуневич Т. Г. Формування культури мовлення студентів-філологів [Електронний ресурс] / Т. Г. Окуневич. - 2013. Режим доступу: http://ekhsuir.kspu.edu/ bitstream/123456789/637/1 5. Проект Національної стратегії розвитку освіти в Україні на 2012-2021 роки [Електронний ресурс].- Режим доступу : http://www.meduniv. lviv.ua/files/ info/nats_strategia.pdf. 6. Техніка формування мовленнєвої культури вчителя [Електронний ресурс]/ Режим доступу: http://pedlib.com.ua/ tehnika- formuvannya-movlennyevo-kulturi-vchitelya.htm.

УДК 372.882

Оксана Фенцик

\title{
ПРОБЛЕМА ВИВЧЕННЯ ЕПІЧНОГО ТВОРУ В ЛІТЕРАТУРНІЙ ОСВІТІ: ІСТОРИКО-МЕТОДИЧНИЙ ОГЛЯД
}

Фенцик О. М. Проблема вивчення епічного твору в літературній освіті: історикометодичний огляд.

Статтю присвячено проблемі критичного аналізу методичної спадщини в галузі 
методики викладання літератури другої половини XX- початку XXI століття. Автор розглядає найгрунтовніші науково-методичні праці з проблеми вивчення епічного твору крізь призму виміру його змісту і форми, виокремлює найважливіші науково-методичні ідеї науковців, які донині посідають важливе місце в теорії i практиці методики викладання літератури.

Ключові слова: наукова спадщина, методика навчання літератури, літературна освіта, методична ідея, художній твір, зміст і форма твору, аналіз, принципи, шляхи, метод, прийом.

Фенцик О. Н. Проблема изучения эпического произведения в литературном образовании: историко-методический обзор.

Статья посвящена проблеме критического анализа методического наследия в области методики преподавания литературы второй половины XX- начала XXI века. Автор рассматривает основные научно-методические работы по проблеме изучения эпического произведения сквозь призму измерения его содержания и формы, выделяет важнейшие методические идеи ученых, которые до сих пор занимают важное место в теории и практике методики преподавания литературы.

Ключевые слова: научное наследие, методика обучения литературы, литературное образование, методическая идея, художественное произведение, содержание и форма произведения, анализ, принципы, пути, метод, прием.

Fentsyk O. M. The problem of epic studying in the literary education: historical and methodological review.

The article deals with the problem of critical analysis of methodological heritage of literature teaching methods of the second half of the XX - beginning of the XXI century. The author examines basical scientific and methodological works on problems of epic work studying through measuring its content and form, identifies the most important scientific and methodical ideas of scientists which still occupy an important place in the theory and practice of literature teaching methods.

Key words: scientific heritage, literature teaching methods, literary education, methodical idea, literary work, content and form of the work, analysis, method, technique.

На формування національної свідомості, високої моралі, активної громадянської позиції, естетичних смаків і ціннісних орієнтацій школярів значною мірою впливає художня література. Однак виховний вплив художнього матеріалу на учнів значно посилиться, якщо вчитель приділить належну увагу спеціальному формуванню в них читацької культури, літературної компетентності, естетичних понять і смаків. Необхідність цієї роботи визначено в Концепції літературної освіти в Україні, Державному стандарті базової і повної загальної середньої освіти, навчальних програмах з української літератури в загальноосвітній школі. Цінним джерелом для подальшого розвитку теорії і практики викладання літератури у школі $€$ науково-методична спадщина з проблеми вивчення літературного твору, осмислення якої допоможе ефективно обрати принципи, шляхи, методи, прийоми та засоби аналізу художнього твору.

У методичній науці вже здавна триває дискусія щодо аналізу літературного твору, зокрема у працях таких науковців: А. Бандура, Г. Бєлєнький, Т. Браже, О. Богданова, Т. Бугайко, П. Волинський, М. Кудряшов, О. Мазуркевич, Н. Молдавська, Н. Падалка, М. Салтикова та ін. Значущими є наукові дослідження Т. Івахненко (методичні концепти 
вивчення літературних творів з урахуванням жанрової специфіки), А. Ситченка (теоретикометодичні засади аналізу художнього твору у шкільному курсі), Л. Панчук (структурування навчальних завдань), О. Слижук (організація читацької діяльності старшокласників), Г. Токмань (екзистенціально-діалогічна концепція викладання літератури в школі) та ін.

Мета статті - дослідити й осмислити в контексті сучасних освітніх перетворень науково-методичну спадщину з проблеми вивчення епічного твору у школі крізь призму виміру його змісту і форми.

Проблема літературної освіти та виховання читачів завжди хвилювала науковців у різні історичні епохи: повне прочитання художнього твору $є$ основою теоретичних знань i практичних вправ з літератури (Ф. Буслаєв); першочергово треба детально розглянути зміст твору, проте слід уникати вульгарного тлумачення літератури або зведення ідейнохудожнього аналізу лише до розмов із приводу прочитаного (В. Стоюнін); значне місце у вивченні літератури посідає самостійна робота школярів (М. Пирогов); розвиток в учнів інтелектуальних здібностей до освоєння морального й естетичного потенціалу мистецтва слова (А. Острогорський).

Головним здобутком методичної науки вже на початку її становлення було ствердження виховної ролі літератури й необхідності засвоєння змісту твору, проте недооцінювався формовий аспект його вивчення.

Принцип аналізу художнього твору в єдності його змісту і форми ствердив у своєму посібнику «Методика викладання літератури» (1938р.) відомий російський методист В. Голубков. Він уважав, що метою аналізу твору є розкриття його ідеї, вказував на виховний вплив мистецтва слова та особливість художніх образів. Було окреслено також шляхи аналізу епічного твору: послідовний (від епізодів до персонажів, через складання плану прочитаного, його переказ та обговорення, розкриття мовних засобів) та проблемнотематичний, коли для аналізу обираються ті епізоди з тексту, які несуть найбільше ідейне навантаження. Однак помітну перевагу мав усе ж соціологічний аспект аналізу епічного твору, зміст якого сприймався як своєрідна ілюстрація до суспільно важливих і класово характерних подій та явищ. Кризу аналізу поглиблювала й неувага фахівців до теорії літератури, тому літературознавці завжди нагадували методистам про необхідність залучення досягнень науки про літературу в шкільну справу її вивчення.

Ще наприкінці 50-х pp. методисти визначили такі принципи аналізу літературного твору: науковості, історизму, єдності змісту й форми, а також естетичний. Вони дозволили говорити про цілісний підхід до вивчення літературного твору, вказували на необхідність його прочитання й особливу увагу приділяли розвитку читацької уяви; застерігали від зведення усієї роботи над твором до моральної проповіді й закликали до безпосереднього опрацювання тексту. Загалом, у 60-80-х рр. минулого століття були визначені основні засадничі положення вивчення епічного твору, які актуальні й досі.

Найбільш грунтовною працею, яка зберегла свою актуальність до наших днів, був тоді посібник для вчителів «Аналіз літературного твору», у якому автори детально висвітлили основні компоненти форми літературного твору, розкриття яких допоможе усвідомити його зміст, та наголошували, що до ідеї твору природніше йти через його форму. Вони стверджували: «Кожний художній твір необхідно вивчати як єдине ціле, в сукупності всіх його ідейно-художніх складників», зважаючи на закон нерозривної єдності змісту i форми [1, с. 3].

На потребу роботи над художніми образами, спостереження за розвитком дії, 
композицією твору, його мовою вперше прямо вказувала М. Рибникова в «Нарисах 3 методики літературного читання» [8, с. 30-33]. На іï думку, літературне читання $\epsilon$ своєрідною школою поглядів, понять і мови. Тому важливо досягти осмислення змісту твору, розуміння авторського задуму, забезпечити сприйняття оповідання, засвоєння його образів та мови, на що й мають бути спрямовані зусилля словесника.

Конструктивний підхід більшості методистів до вивчення художнього твору дав змогу виробити найбільш прийнятні в школі шляхи його аналізу. Ще Т. Бугайко і Ф. Бугайко, наприклад, схарактеризували послідовний аналіз - «за ходом дії, від розділу до розділу» [2, с. 52], який передбачає, на їхню думку, розгляд художніх компонентів у взаємозв’язку і 3 авторською оцінкою дійсності. 3'являється чітке розуміння того, що цілісний аналіз - не якийсь окремий шлях роботи над твором, а його мета, умова якісного проведення. Реалізується він і внаслідок застосування історичного підходу до зображуваного, що сприяє тіснішому зв'язку літературної освіти й потреб кожної особистості, єдності навчання із потребами життя й духовними потребами людини. Цілісний аналіз художнього твору забезпечується на основі таких принципів його проведення, як єдність змісту і форми, думки і почуття.

Цінними є роздуми О. Мазуркевича, який уважав, що на уроках літератури учні повинні досліджувати текст художнього твору з усім багатством змісту і форми, читати, роздумувати над ним, проникати в глибінь слова письменника, художніх образів. Проте науковець зауважував: «Надмірно складний i одноманітний аналіз творів, спрощені трактування літературних явищ призводять до того, що вивчення художньої літератури втрачає свою образно-емоційну силу» [3, с. 178].

На виражальних якостях твору наголошує й К. Фролова, яка вказує на необхідність обгрунтованих суджень про ідейний зміст твору, виведених на основі його всебічного аналізу. Саме з аналізом вона пов'язує не лише мислиннєву, а й емоційну активність читачів, переконуючи, що поряд з єдністю змісту й форми в художньому тексті варто говорити і про єдність читацької (та й авторової) думки й почуття.

Склад твору вже сам у собі, - уважають Є. Маймін і Е. Слиніна, - передбачає норми його тлумачення: його компоненти даються й беруться у всій складності контексту, проливають світло один на одного й через зіставлення частин, внаслідок цілісного охоплення всього витвору неминуче має розкритися центральна залежність та естетичний смисл як окремих частковостей, так і всього цілого. Естетичний вплив художнього твору на читачів неодмінно супроводжується емоціями, викликає в читачів відповідні настрої, сприятливі для тих чи тих роздумів, висновків і вчинків. Тому активізується аналіз у єдності емоційного й логічного чинників не лише ліричного чи ліро-епічного твору, а й епічного. Серед найбільш традиційних у школі називаються послідовний, пообразний і проблемно-тематичний шляхи аналізу художнього твору (Т. Бугайко, В. Неділько, 3. Рез). Перспективними методисти вважають людинознавчу концепцію викладання літератури Є. Ільїна, чиї ідеї навчального виховання набули наприкінці минулого століття великої популярності.

Цінним внеском у методику літератури $є$ праці відомого вітчизняного науковця $€$. Пасічника. На його думку, «зміст і форма літературного твору - нерозривна діалектична єдність. Художній твір повинен бути сприйнятий учнями як цілісна ідейно-художня структура» [6, с. 239]. Цю думку науковець підкріплює висуненням основних наукових принципів шкільного аналізу твору: врахування положення про діалектичну єдність змісту і форми; пильна увага до тексту; історичний підхід до осмислення літературних явищ; 
«емоційний резонанс» читача у процесі сприйняття художнього образу; застосування дидактичних принципів аналізу.

Потребу глибокого осмислення читачем естетичного потенціалу художнього твору висував Б. Степанишин, підкреслюючи, що «...літературний твір постає перед учнями не як конгломерат тропів, фігур, композиційних і позакомпозиційних засобів, а як живий i пульсуючий витвір красного письменства» [10]. Важливо не лише помічати в тексті ті чи ті художні засоби, і не тільки визначати їхню ідейно-художню роль, а й відчувати з того задоволення, яке стосовно мистецтва називають естетичним. У спілкуванні з твором відбувається моральне самозаглиблення й естетичний зв'язок читача 3 автором, внаслідок чого здійснюється особистісний розвиток школярів. Своєрідними каналами цього зв'язку в літературному творі є саме компоненти його форми, на що вказував ще О. Потебня, водночас маючи на увазі й необхідність формування в читачів «агрегатів сприйняття», готових розкодувати художні деталі й картини.

Науковці-методисти О. Бандура i Н. Волошина застерігали і від надмірного заглиблення у зміст твору, що може призвести до абстрактного соціологування з приводу прочитаного, й навпаки - щоб не стати на шлях формалізму. Називаючи традиційні шляхи аналізу художнього твору (пообразний, проблемно-тематичний, послідовний), О. Бандура й Н. Волошина визначали й нові: мовно-стильовий та композиційний, наполягали на оновленні форм і методів вивчення літератури в школі.

Науковці С. Пультер та А. Лісовський звертають увагу на особливості сприймання художнього твору, з'ясовують основні складники його змісту й форми: тему, ідею, характер, тип, композицію, сюжет. 3-поміж методичних прийомів опрацювання епічних творів вони називають такі: переказ, усне малювання, різні види творчих і самостійних робіт [7].

Шляхи аналізу значного за обсягом епічного твору на початку 90-х рр. висвітлюються групою літературознавців (В. Марко, Г. Клочек, В. Панченко та ін.). Вони стверджують: «... найточніше розуміння твору досягається лише вмілим аналізом його змісту й форми» [4, с. 5] і подають конкретні рекомендації, як це краще зробити. По-перше, вони вважають, що доцільно ширше практикувати аналіз, який би розпочинався з вивчення форми, а відтак вів би до розуміння змісту, і накреслюють схему аналізу твору в єдності його змісту й форми: «від деталі до провідної думки» твору [5, с. 6].

Навчально-технологічну концепцію літературного аналізу пропонує А. Ситченко [9], розробляючи її на прикладі прозових творів, що вивчаються в базовій і старшій школі. Його теоретична модель навчання учнів аналізу твору побудована з урахуванням специфіки мистецтва слова й передбачає реалізацію як традиційних, так й інноваційних принципів здійснення цієї роботи. Серед перших чільне місце посідає принцип аналізу твору в єдності його змісту й форми, серед інноваційних - принцип єдності емоційного й логічного факторів літературного навчання, адже найбільш повне усвідомлення учнями ідейно-художньої цілісності твору забезпечується під час розкриття взаємодії в конкретному тексті компонентів його змісту й форми, у процесі й унаслідок чого активізуються й повертають до конструктивного русла читацькі думки й почуття.

На основі викладеного вище можна стверджувати, що науковий підхід до вивчення художнього твору має вибудовуватися з урахуванням традицій (на основі набутого досвіду) й інновацій. Аналіз науково-методичної спадщини надав змогу визначити деякі аспекти вивчення художнього твору: слід керуватися принципами єдності змісту і форми та думки й почуття; науковості, історизму; дати учням уявлення про літературний твір як цілісне ідейно- 
естетичне явище, навчити їх сприймати й осмислювати художній твір як факт мистецтва та через емоційне сприймання словесно-художнього мистецтва усвідомлювати сенс людського життя; увагу учнів слід зосереджувати не лише на подіях твору, а й на тих його компонентах, художніх деталях, які допоможуть виявити виразність, спостерігаючи красу мови, образних висловів, описів, композиційної довершеності тексту; вчити школярів помічати метафоричну форму й переносний зміст, підтекст виучуваного твору; слід однаково уникати як надмірної соціологізації, так і формалізму в роботі над твором; аналіз твору має будуватися 3 урахуванням його жанрово-родової специфіки; уникати шаблонності, урізноманітнювати шляхи, методи і прийоми вивчення художнього твору.

Актуалізація потреби осмисленого й естетичного сприйняття художнього твору зумовлюється взаємозв'язком його змісту і форми, розкрити усю складність якого допоможуть інноваційні технології роботи над текстом - саме в цьому й убачаємо перспективу подальших досліджень.

\section{Література}

1. Бровко І. Б. Аналіз літературного твору: [посіб. для вчителів] / І. Б. Бровко, М. Х. Коцюбинська, Г. К. Сидоренко. - Київ : Рад. школа, 1959. - 166 с. 2. Бугайко Т.Ф. Навчання і виховання засобами літератури / Т. Ф. Бугайко, Ф. Ф. Бугайко. - Київ : Рад. школа, 1973. - 176 с. 3. Мазуркевич О. Р. Метод і творчість / О. Р. Мазуркевич. - Київ : Рад. школа, 1973. - 255 с. 4. Марко В. П. І вічна таїна слова: аналіз великого епічного твору : [посіб. для вчителя] / В. П. Марко, Г. Д. Клочек, В. Є. Панченко і ін. - Київ : Рад. школа, 1990. - 205 с. 5. Наукові основи методики літератури: [навч.-метод. посіб.] / за ред. д. п.н, проф., чл.-кор. Н. Й. Волошиної. - Київ : Ленвіт, 2002. - 344 с. 6. Пасічник Є. А. Методика викладання української літератури в середніх навчальних закладах: [навчальний посібник для студентів вищих закладів освіти] / Є. А. Пасічник. - Київ : Ленвіт, 2000. - 384 с. 7. Пультер С. О. Методика викладання української літератури в середній школі / С. О. Пультер, А. М. Лісовський. - Житомир : Полісся, 2000. - 163 с. 8. Рыбникова М. А. Очерки по методике литературного чтения / М. А. Рыбникова. - Москва : Просвещение, 1985. - 288 с. 9. Ситченко А. Л. Навчально-технологічна концепція літературного аналізу / А. Л. Ситченко. - Київ : Ленвіт, 2004. - 305 с. 10. Степанишин Б. І. Викладання української літератури в школі / Б. І. Степанишин. - Київ : Проза, 1995. - 254 с.

\section{ДИСТАНЦІЙНІ ОСВІТНІ КУРСИ: МІЖНАРОДНИЙ ДОСВІД}

Шалацька Г. М. Дистанційні освітні курси: міжнародний досвід.

У статті описано досвід розроблення дистанційного курсу на основі британської навчальної платформи FutureLearn, здійснено аналіз міжнародного досвіду роботи та організації дистанційного освітнього курсу. Зроблено спробу виявити тенденції та шляхи упровадження новітніх технологій у навчанні та підвищенні кваліфікаційного рівня у вітчизняну педагогічну практику.

Ключові слова: дистанційна освіта, курс, комп’ютерні технології, Інтернет, підвищення кваліфікації, навчальна платформа, тьютор.

Шалацкая А. Н. Дистанционные образовательные курсы: международный опыт.

В статье описан опыт разработки дистанционного курса на основе британской 